\title{
PREDYSPOZYCJE INDYWIDUALNE STUDENTÓW WYRÓŻNIAJĄCYCH SIĘ
}

\author{
INDIVIDUAL CAPACITIES OF OUTSTANDING STUDENTS
}

\author{
KRYSTYNA JANASZEK
}

\begin{abstract}
The article deals with individual qualities of students who achieve very good results in foreign language learning. A survey conducted among students of modern languages at Szczecin University has shown that certain capacities contribute to successful language learning. These capacities include: linguistic and logical-mathematical intelligence, extrovert personality features, a strong temperament, courage to apply communicative strategies, strong internal motivation and the ability to handle difficult situations.
\end{abstract}

Krystyna Janaszek, Uniwersytet Szczeciński, Szczecin - Polska.

W latach 2006-2009 prowadziłam badania ankietowe, w których uczestniczyło 212 studentów Wydziału Filologicznego Uniwersytetu Szczecińskiego - reprezentantów trzech specjalności neofilologicznych: angielskiej, romańskiej, słowiańskiej. Chodziło o uwypuklenie różnic indywidualnych w zakresie określonych predyspozycji (umysłowych, poznawczych, osobowościowych, motywacyjnych) i odniesienie ich do efektów kształcenia językowego. Interpretowano także różnice $\mathrm{w}$ zachowaniach związanych $\mathrm{z}$ przezwyciężaniem trudności w nauce języka obcego. Aby rozpoznać sygnalizowane różnice, zastosowano metodę analizy międzygrupowej, uwzględniającą samoopis i szacowanie. Z całości badanej próby wyodrębniono grupę studentów wyróżniających się (grupa I - średnia toku studiów: 4, 6-4, 73) oraz grupę studentów dostatecznych (grupa II - średnia toku studiów: 3, 0-3, 49). Oprócz tradycyjnej ankiety badającej poszczególne predyspozycje posłużono się dodatkowo propozycją psychologa P. Szaroty ${ }^{1}$, którego polska lista przymiotnikowa (PLP) stała się oryginalnym narzędziem do diagnozy czynników w ramach „Pięcioczynnikowego Modelu Osobowości” (PMO). Pięciu czynnikom (ugodowość, sumienność, dynamiczność, pobudliwość, intelekt) przypisano przymiotnikowe odpowiedniki (60 cech). Zadaniem

${ }^{1}$ P. S z a r o t a, Polska Lista Przymiotnikowa (PLP): narzędzie do diagnozy Pięciu Wielkich Czynników Osobowości, „Studia Psychologiczne”, Warszawa 1995, t. XXXIII. 
studentów było określenie, w jakim stopniu każdą z cech można odnieść do ich osoby. Odpowiedzi sygnalizowano według pięciostopniowej skali wskaźników cech (całkowicie nietrafne, raczej nietrafne, równie trafne jak nietrafne, raczej trafne, całkowicie trafne). Cechy badanych weryfikowane były przez ich bliskich kolegów według tej samej skali.

Wyniki moich badań zaprezentuję poniżej w pięciu kolejnych punktach, w ramach wspomnianych płaszczyzn (predyspozycji).

\section{1) Inteligencja i zdolności}

Warto przypomnieć, że inteligencja to termin, który nie doczekał się w psychologii ogólnie przyjętej definicji. Niektórzy psychologowie uważają ją za podstawowy czynnik decydujący o życiu i zachowaniu człowieka, inni zaś w ogóle negują jej istnienie. Niezależnie od szczegółowych sformułowań inteligencję wiąże się zwykle z pewną ogólną zdolnością umysłu do uczenia się i rozwiązywania zadań².

Badania prowadzone $\mathrm{w}$ obrębie tej problematyki potwierdzają, że inteligencja wyrażona tzw. ilorazem inteligencji (I.I.) wykazuje korelację dodatnią z ogólną łatwością uczenia się. Wszystkie potwierdzają także lepsze wyniki uczniów o wyższym ilorazie inteligencji (zależność od +0,40 do $+0,50$, a więc istotna na skali współczynnika korelacji).

W ostatnich latach w literaturze psychologicznej (i glottodydaktycznej) pojawiły się propozycje, które nawiązując do badań nad inteligencją przełamują to tradycyjne do niej podejście. W teorii wielu inteligencji H. Gardnera podkreśla się, że efektywność działania i rozwiązywania zadań (problemów) nie zależy wyłącznie od inteligencji psychometrycznej, lecz także od innych zdolności (inteligencji).

Gardner wyróżnia między innymi takie oto rodzaje inteligencji:

- Inteligencja językowa - rozumiana jako umiejętność właściwego komunikowania się; pozwala odpowiednio dobierać słowa, płynnie formułować wypowiedzi, poprawnie pisać, operować dużym zasobem słownictwa.

- Inteligencja logiczno-matematyczna, która potwierdza umiejętność rozumowania; pozwala posługiwać się relacjami pojęć abstrakcyjnych i rozumieć je.

- Inteligencja interpersonalna - jest zdolnością do rozumienia relacji międzyludzkich, ułatwia współdziałanie z ludźmi.

- Inteligencja intrapersonalna - polega na rozumieniu, a zwłaszcza rozróżnianiu własnych uczuć i emocji.

- Inteligencja muzyczna - wskazuje na umiejętność wytwarzania i rozumienia treści, których nośnikiem jest dźwięk³.

2 I. E k e 1 i in., Maty stownik psychologiczny, Warszawa 1965.

${ }^{3}$ H. G a r d n e r, Inteligencje wielorakie. Teoria w praktyce, Poznań 2002, s. 46. 
W relacjonowanych badaniach porównywano powyższe zdolności. W całej badanej próbie podobnie (wręcz identycznie) wskaźnikowano wartości odnoszące się do inteligencji interpersonalnej i muzycznej. Różnice ujawniły się tylko $\mathrm{w}$ ramach inteligencji językowej i logiczno-matematycznej. Przede wszystkim w grupie studentów wyróżniających się oba rodzaje inteligencji występowały jako wymiary uzupełniające się. Osiągały też wyższe wartości procentowe.

Powodzeniu w akwizycji języka obcego sprzyjają zdolności językowe. Na ogólną zdolność językową składa się suma poszczególnych uzdolnień. Podstawę uzdolnień stanowią specyficzne umiejętności. Przytacza je m.in. W. Pfeiffer. Są to:

- kodowanie fonetyczne, czyli łatwość opanowania wymowy w połączeniu z postacią graficzną dźwięków;

- wrażliwość gramatyczna, czyli łatwość rozpoznawania gramatycznych funkcji wyrazów w zdaniu;

- umiejętność indukcyjna, czyli umiejętność rozpoznawania wzorców reguł gramatycznych;

- pamięć mechaniczna - umiejętność uczenia się w krótkim czasie dużej liczby asocjacji i łatwość zapamiętywania materiału gramatycznego przez dłuższy czas 4 .

Badani studenci sygnalizowali swoje umiejętności w oparciu o listę zdolności cząstkowych, które prezentuje m.in. I. Kurcz. Wybierali spośród następujących:

- pamięć mechaniczna słuchowa - łatwość zapamiętywania brzmienia głosek, wyrazów, zwrotów;

- pamięć mechaniczna wzrokowa - łatwość zapamiętywania pisowni wyrazów;

- zdolność rozróżniania głosek (fonemów) - słuch fonematyczny;

- zdolność artykulacyjna - łatwość wymowy głosek lub ich naśladowania;

- zdolność naśladowania intonacji oraz rymu, melodii zdania (spokrewniona ze zdolnościami muzycznymi);

- zdolność do analizy językowej - zdolność do wnioskowania o regułach gramatycznych (np. na podstawie zdań ze sztucznego języka) $)^{5}$.

W całej badanej próbie podobnie sklasyfikowano dwa rodzaje zdolności: zdolność do analizy językowej oraz zdolność naśladowania intonacji, rytmu, melodii zdania. Uznano je za umiejętności charakterystyczne dla przeciętnego studenta.

${ }^{4}$ W. P f e i f f e r, Nauka języków obcych. Od praktyki do praktyki, Poznań 2001, s. 105.

${ }^{5}$ I. K u r c z, Psychologia języka i komunikacji, Warszawa 2000, s. 183-184. 
W grupie studentów wyróżniających się (inaczej niż dostatecznych) na plan pierwszy wysunęły się kwestie związane z pamięcią. Odnotowano przewagę tzw. wzrokowców, zdecydowanie akcentowano pamięć mechaniczną słuchową. Eksponowano (nieuwzględnioną w powyższych punktach) pamięć logiczną. Dodatkowy nacisk położono na zdolność artykulacyjną i słuch fonematyczny.

\section{2) Typ osobowości, typ temperamentu}

W ramach predyspozycji osobowościowych uwzględniono dwa typy osobowości (ekstrawertywny, introwertywny) oraz cztery typy temperamentu (sangwiniczny, choleryczny, flegmatyczny, melancholiczny).

Istotnym wyróżnikiem typu osobowości jest poziom energetyczny (wysoki /niski), a co za tym idzie ukierunkowanie energii osobowości (na zewnątrz/ku wnętrzu). Ekstrawersja (E) charakteryzuje się stałym wyższym poziomem energii własnej, który determinuje konieczność kierowania jej na zewnątrz, w stronę ludzi i zewnętrznych zdarzeń. Ekstrawertycy to ludzie otwarci na otoczenie, gotowi do zmian, ciekawi świata. Osoby te są szybkie w działaniu, pomysłowe, spontaniczne. Introwertycy (I) mają niższy poziom energii, który powoduje zatrzymanie jej i skupienie w sobie. Rozładowanie energii następuje minimalnie i stopniowo. Osoby introwertywne unikają kontaktu $\mathrm{z}$ otoczeniem, gdyż wystarczająco realizują się poprzez subiektywne stany wewnętrzne. Mają skłonność do działań rozważnych, planowanych, przemyślanych; są refleksyjne, głęboko się koncentrują ${ }^{6}$.

W tych badaniach typ osobowości analizowano $\mathrm{w}$ oparciu o propozycję S. Hirsha i I. Kummerowa7, na którą złożyło się 28 charakterystyk prezentowanych $\mathrm{w}$ trzech kategoriach relacji człowieka $\mathrm{z}$ otoczeniem (sposoby zachowania się, sposoby komunikowania się między ludźmi, stosunki z ludźmi). Właściwością odróżniającą studentów bardzo dobrych (grupa I) od pozostałych badanych (szczególnie zaś od studentów dostatecznych) okazała się wyłączność cech ekstrawertywnych (umiejętność komunikowania się, łatwość nawiązywania znajomości, szybka reakcja na bodźce płynące $\mathrm{z}$ otoczenia). Podobnym wyborom w II grupie zawsze towarzyszyły opisy zachowań introwertywnych.

Cechy temperamentalne także różnicują ludzi, nieco inne są jednak kryteria, które mają tu decydujące znaczenie. W zasadzie wszystkie wiodące po dzień dzisiejszy typologie temperamentu nawiązują do starożytnej Koncepcji Hipokratesa-Galena, której podstawę stanowiło wyodrębnienie czte-

${ }^{6} \mathrm{H}$. A r g y 1 e, Psychologia stosunków międzyludzkich, Warszawa 2002, s. 141; H.M. E y s e n c k, Podpatrywanie umystu, Gdańsk 1966, s. 153.

7 S. H i r s h, J. K u m m e r o w, Psychologia. Typy życiowe, Wrocław 1997, s. 10-13. 
rech wspomnianych typów. Rosyjski badacz I.P. Pawłow ${ }^{8}$ odniósł do tych typów właściwości mogące powodować różnice między jednostkami. Właściwości te to cechy układu nerwowego: siła procesu pobudzania i hamowania, równowaga i ruchliwość procesów nerwowych. W literaturze psychologicznej każdemu z typów przypisuje się cechy wiodące. Oto one:

- sangwinik - typ silny, zrównoważony, ruchliwy (towarzyski, otwarty, wrażliwy, gadatliwy, żywy, przywódczy, beztroski, niefrasobliwy);

- choleryk - typ silny, niezrównoważony, z przewagą pobudzania (optymistyczny, zmienny, aktywny, impulsywny, wybuchowy, drażliwy, agresywny);

- flegmatyk - typ silny, zrównoważony (powolny, pojednawczy, ostrożny, kontrolujący się, łagodny, solidny, poważny, bierny);

- melancholik - typ słaby (spokojny, zamyślony, lękliwy, pesymistyczny, markotny, nietowarzyski, sztywny).

Typ temperamentu, podobnie jak typ osobowości, wiąże się z zasobami energetycznymi jednostki. Od nich zależy odpowiednie pobudzenie organizmu i poziom zapotrzebowania na stymulację. Pobudzenia dokonuje sprzężony z układem nerwowym układ hormonalny, który wydziela do krwi odpowiednie substancje. Stan pobudzenia zwiększa natężenie pracy umysłowej i ułatwia skupienie uwagi na przedmiocie nauki, przez co powoduje lepsze wykorzystanie czasu poświęconego na nią, a więc i przyspieszenie postępów. Organizm ludzki dąży zawsze do utrzymania stanu równowagi, którego wynikiem jest optymalny poziom pobudzenia. Jest to poziom, przy którym sprawność działania jest największa. Takiemu poziomowi pobudzenia towarzyszą zwykle pozytywne emocje.

W Polsce badaniami nad temperamentem zajmował się m.in. T. Lewowicki. Dowiódł on, że efektywne uczenie się determinowane jest przez cechy układu nerwowego: pobudzanie i hamowanie. Duża ruchliwość tych procesów oraz ich równowaga sprzyjają efektywnemu uczeniu się. Flegmatycy i melancholicy uczą się według niego mniej efektywnie, napotykając na trudności. Poza tym uczniów o słabym typie układu nerwowego oceny negatywne zniechęcają do nauki ${ }^{9}$.

Wydaje się, że stwierdzenia tego typu jak powyższe wymagają uściślenia. Z przeprowadzonych badań wynika, że nie poszczególne typy (prawie nigdy nie występują one $\mathrm{w}$ tzw. czystej postaci), a ich szczegółowe wskaźniki mają wpływ na efekty kształcenia. W relacjonowanych badaniach w całej badanej próbie dominował układ temperamentalny typu S-CH (sangwiniko-choleryk). Studentów bardzo dobrych od tych gorszych różniły kon-

8 I.P. P a w $ł$ o w, Dwadzieścia lat badań wyższej czynności nerwowej (zachowania się zwierzat), Warszawa 1952.

9 T. L e w o w i c k i, Psychologiczne różnice indywidualne a osiagnięcia uczniów, Warszawa 1975, s. 113-114. 
kretne cechy. W grupie studentów wyróżniających się układowi S-CH częściej towarzyszyły cechy flegmatyka (np. solidny), natomiast w grupie studentów dostatecznych - cechy melancholika (np. spokojny). Odnotowano także, że najlepsi studenci rzadziej od innych eksponowali cechy choleryka (zmienny, optymistyczny).

W świetle tej analizy z całą pewnością można stwierdzić, że studiowaniu języka obcego zdecydowanie sprzyjają:

- ekstrawertywne charakterystyki osobowości, odzwierciedlające otwarte relacje $\mathrm{z}$ otoczeniem, które polegają na łatwości i chęci komunikowania się i kontaktowania z ludźmi, z uwzględnieniem szybkich zdecydowanych reakcji na bodźce płynące $z$ otoczenia;

- cechy temperamentów silnych, w układzie S-CH-F, o określonych parametrach determinujących równowagę.

Dodatkowych informacji o osobowości badanych dostarczyły wyniki ankiety skonstruowanej $\mathrm{w}$ oparciu o propozycję wspomnianego na początku Szaroty (PMO-PLP). Diagnozowano pięć czynników osobowości:

- ugodowość (połączenie życzliwości i wyrozumiałości oraz tendencja do zachowań altruistycznych);

- sumienność (obowiązkowość połączona z motywacją osiągnięć i życiową rozwagą);

- dynamiczność (mieszanka operatywności, energiczności i ruchliwości);

- pobudliwość (impulsywność i emocjonalność);

- intelekt (kreatywność połączona z inteligencją).

Na podstawie tej listy czynników oraz towarzyszących im 60 wskaźników wyłoniono cechy swoiste dla określonych grup. Otóż grupę I wyróżniały: intelekt (83\%) i sumienność (75\%) (lista przymiotnikowa: bystry, inteligentny, myślący, rozumny, dokładny, obowiązkowy, sumienny). U studentów dostatecznych dominowała ugodowość (45\%); na dalszym planie pojawiły się: sumienność (37\%) i intelekt (35\%). Elementem najbardziej różnicującym obie grupy okazał się intelekt.

Z bezpośrednich wypowiedzi studentów wynika, że spośród 60 wskaźników znajdujących się na liście przymiotnikowej 20 wywiera pozytywny wpływ na proces studiowania języka. Większość z nich to cechy obejmujące „intelekt” i „sumienność”. Wśród 13, które w opinii badanych utrudniają ten proces, aż 12 wiąże się z „pobudliwością" (przykłady: nerwowy, impulsywny, pobudliwy, nieopanowany).

\section{3) Style myślenia, style poznawcze i strategie komunikacyjne}

W ramach kolejnej płaszczyzny badawczej rozpatrywano różnice dostrzegalne $\mathrm{w}$ zachowaniu i funkcjonowaniu poznawczym $\mathrm{w}$ obrębie następujących zagadnień: 
- style myślenia,

- samodzielność w sytuacjach poznawczych (zależność - niezależność od pola),

- kontrola przebiegu własnych czynności poznawczych (refleksyjność - impulsywność),

- sposoby organizowania doświadczenia językowego (style: ujmowania oraz generalizacji i porządkowania zjawisk).

Różnice dostrzegalne w sposobach myślenia objawiają się stylami myślenia. Teoria poznawczego samokierowania (J. Sternberga i E. Grigorenki) jest ideą wziętą z codziennej obserwacji. Głosi ona, że różne style spotykane $\mathrm{W}$ świecie stanowią w pewnym sensie odbicie stylów ulokowanych w umyśle człowieka. Kryteria poznawczego samokierowania uwzględniają 13 stylów (legislacyjny, wykonawczy, oceniający, monarchiczny, hierarchiczny, oligarchiczny, anarchiczny, lokalny, globalny, zewnętrzny, wewnętrzny, liberalny, konserwatywny). Style te to preferowane sposoby wykorzystania zdolności w codziennych interakcjach ze środowiskiem. W określonej sytuacji wybiera się ten styl, który zapewnia najlepszą adaptację do poznawczych wymagań otoczenia, w konsekwencji zaś optymalną skuteczność funkcjonowania poznawczego.

Wspólnym dla wszystkich badanych okazał się styl liberalny. Cechuje on osoby, które wytyczają sobie w życiu własną drogę i kierują się swoimi zasadami. Poza tym jednym stylem respondenci poszczególnych grup wybierali odmienne.

Działania grupy I (studenci wyróżniający się) związane są z preferencjami dla zadań szczegółowych, w których ważne są detale i ceniona jest precyzja $\mathrm{w}$ działaniu (styl lokalny), a ponadto uwzględnia się priorytety (styl hierarchiczny) i docenia zadania podejmowane bez udziału innych osób (styl wewnętrzny). Grupa II (studenci dostateczni) zdecydowanie bardziej lubi działać wspólnie z innymi (styl zewnętrzny), częściej stawia na indywidualne pomysły i rozwiązania (styl legislacyjny), preferuje zadania o dużym stopniu ogólności (styl globalny).

Większość całej badanej próby $(75 \%)$ charakteryzuje „niezależność od pola". Ułatwia ona selektywne utrzymywanie aktywności na określonym przedmiocie (powstrzymywanie się od kierowania jej na bodźce uboczne) oraz wydobywanie określonych elementów z tego, co stanowi całość pola percepcyjnego (wybiórcze zapoznawanie się z tekstem, wyszukiwanie informacji na dany temat, zwracanie uwagi tylko na to, co istotne dla wykonywanego zadania). Oznacza to spore umiejętności w porządkowaniu i organizowaniu materiału.

Przebieg własnych czynności poznawczych podlega mniejszej lub większej kontroli (impulsywność - refleksyjność). W obrębie tego zagadnie- 
nia nie udało się ustalić specjalnych różnic między grupami. Działania większości badanych (62\%) związane są z tzw. impulsywnością. Z jednej strony jest ona przejawem braku troski o poprawność generowanej wypowiedzi, z drugiej zaś pomaga wówczas, gdy wymagana jest spontaniczność i płynność przebiegu czynności, szczególnie mówienia.

Indywidualne preferencje poznawcze dotyczą także sposobów organizowania doświadczenia językowego. Uwzględniają one:

- logiczny lub warstwowy styl ujmowania zjawisk językowych,

- szeroki lub wąski styl generalizacji i porządkowania zjawisk językowych.

Charakterystyczny dla studentów wyróżniających się jest logiczny styl ujmowania zjawisk, który dominuje w tej grupie nad stylem warstwowym. Oznacza on skłonność do narzucania na rzeczywistość całościowej siatki podziałów, chęć posiadania kompleksowego obrazu całości. Jest przeciwieństwem stylu warstwowego, który przejawia się tendencją do gromadzenia informacji bez potrzeby ich porządkowania i występuje znacznie częściej w grupie II.

Zjawiskiem symptomatycznym dla badanej próby jest szeroki styl generalizacji. Osoby o szerokiej kategoryzacji, choć odznaczają się łatwością uogólniania, często ujawniają tendencję do zbyt szerokich generalizacji. Studenci wyróżniający się przejawiają ją rzadziej niż inni.

Podsumowując ten fragment badań, można stwierdzić, że cechą sprzyjającą całej badanej próbie jest samodzielność poznawcza. W przypadku studentów najlepszych jest ona podbudowana umiejętnością koncentrowania się na szczegółach, znaczną precyzją w działaniu, sporą potrzebą porządkowania zjawisk językowych, rozwagą $\mathrm{w}$ przejawianiu tendencji do zbyt szerokich generalizacji.

W badaniach poruszono także problem strategii, które traktowane są jako zorganizowane działania zmierzające do rozwiązania konkretnego problemu (zadania) i osiągnięcia tą drogą zamierzonego celu. Strategie komunikacyjne polegają na przezwyciężaniu trudności językowych i osiąganiu celów komunikacyjnych.

Przejrzystą klasyfikację takich działań przytacza M. Szałek ${ }^{10}$. Wskazuje on na dwa podstawowe typy produktywnych strategii komunikacyjnych: redukcji (zmniejszonego ryzyka) i osiągnięć (zwiększonego ryzyka). Strategia redukcji formalnej odnosi się do formy wypowiedzi, polega na porozumiewaniu się za pomocą uproszczonego języka (np. unikanie wypowiedzi błędnych lub mało płynnych). Strategia redukcji funkcjonalnej przekłada się na treść wypowiedzi (zmiana tematu, udawanie nieporozumienia, res. 66-69.

10 M. S z a ł e k, Sposoby podnoszenia motywacji na lekcjach języka obcego, Poznań 1992, 
zygnacja z wypowiedzi). Osoby, które preferują strategie osiągnięć, starają się porozumiewać $\mathrm{w}$ języku obcym używając go za wszelką cenę. Stosują wówczas głównie strategie kompensacyjne. Ich istotą jest wyrażanie zamierzonej treści $\mathrm{w}$ inny sposób, zastępowanie jednych środków językowych innymi, z reguły uboższymi i mniej adekwatnymi. Operacja taka wykonywana jest bądź z pomocą interlokutora (strategia kooperacyjna), bądź bez jego udziału (strategia niekooperacyjna).

Najważniejsze różnice ujawniono w stosowaniu strategii redukcji. Bardzo dobrzy studenci odwołują się do tego typu działań z trzykrotnie mniejszą częstotliwością niż pozostali. Grupa ta najczęściej korzysta z niekooperacyjnych strategii osiągnięć opartych na języku przyswajanym. Zwykle jest to zastępowanie nieznanego wyrazu lub zwrotu jego opisem lub stosownym przykładem albo zastąpienie danego wyrazu innym. Rzadko stosowane są strategie oparte na innych językach (tłumaczenie dosłowne, czy tzw. przełączenie kodu - przejście z języka przyswajanego na język ojczysty lub inny język obcy). Strategie niewerbalne (gesty, mimika) oraz kompensacyjne strategie kooperacyjne, wyrażające się prośbą o pomoc, także należą w przypadku tej grupy do rzadkości.

\section{4) Motywy studiowania języka obcego}

Dla potrzeb badań wyselekcjonowano 16 motywów uwzględniających dwa typy motywacji (integrującą, instrumentalną), a także inne motywy szczegółowe. Motywację integrującą rozpatrywano w kategoriach duchowego powinowactwa $z$ językiem i kulturą danego kraju oraz satysfakcji z uczenia się języka.

Motywację instrumentalną odniesiono do przydatności języka w przyszłej pracy, podróżach i kontaktach międzynarodowych. Listę tych motywów uzupełniono o dodatkowe motywy szczegółowe, o których wspomina Pfeiffer:

- motyw poznawczy (ciekawości) - chęć poznania, przeżycia „czegoś nowego",

- motyw użyteczności - zrozumienie wartości języka dla indywidualnych studiów; „poszerzenie horyzontów”,

- motyw komunikacyjny - chęć porozumiewania się z ludźmi,

- motyw prestiżu - potrzeba dowartościowania się poprzez znajomość języka obcego ${ }^{11}$.

Pośród wszystkich motywów dominował motyw komunikacyjny.

Fakt oddziaływania czynników motywacyjnych w określonej konfiguracji ustalił ostateczny kształt motywacji, którą $\mathrm{w}$ odniesieniu do responden-

11 W. P f e if f e r, op. cit., s. 112-113. 
tów całej badanej próby uznano za instrumentalno-integrującą. Określone grupy różnił tylko charakter tej motywacji:

- wewnętrzny w przypadku studentów wyróżniających się,

- zewnętrzny w przypadku pozostałych studentów.

Studenci grupy I eksponowali satysfakcję i przyjemność, jaką daje uczenie się języka obcego. Większą wagę przywiązywano tu do walorów poznawczych studiowania i korzyści płynących ze znajomości języka w przyszłości. Studenci dostateczni identyfikowali się z kulturą narodu, podkreślając przydatność języka na emigracji. Wystąpiły tu także motywy $\mathrm{z}$ grupy lękowych.

\section{5) Sposoby przezwyciężania trudności}

Różnice indywidualne dotyczą także umiejętności odnalezienia się w trudnej sytuacji i reakcji na stres. Dowiedziono, że sytuacje trudne (np. zła ocena, trudny egzamin) hamują aktywne postawy. Oceny negatywne zniechęcają zarówno dobrych, jak i gorszych studentów.

W sytuacji niekomfortowej grupa I stara się zawsze zachować tzw. zimną krew i mimo wszystko wyzwalać pozytywne emocje. Studenci wyróżniający się lepiej niż inni radzą sobie ze stresem, stosując styl skoncentrowany na zadaniu. Polega on na tym, że w sytuacji trudnej podejmuje się wysiłki zmierzające do szybkiego rozwiązania problemu, a poprzez jego zgłębienie dąży się do natychmiastowej zmiany sytuacji mniej korzystnej na bardziej korzystną.

Gorszym studentom w podobnych sytuacjach towarzyszą blokady psychiczne i negatywne stany emocjonalne uniemożliwiające skuteczne działanie.

Na zakończenie warto podsumować te czynniki, które zdecydowanie sprzyjają sukcesowi. Wyodrębniono je na podstawie dostrzeżonych różnic. Są to:

1) Harmonijnie uzupełniające się dwa wymiary inteligencji: językowa i logiczno-matematyczna (wspomagane inteligencją interpersonalną i muzyczną).

2) Słuch fonematyczny, zdolność artykulacyjna oraz silnie eksponowane: pamięć mechaniczna i pamięć logiczna.

3) Ekstrawertywne charakterystyki osobowości, odzwierciedlające otwarte relacje z otoczeniem, łatwość i chęć komunikowania się, szybkie reakcje na bodźce płynące $\mathrm{z}$ otoczenia (zdecydowane ukierunkowanie energii osobowości na zewnątrz).

4) Cechy temperamentów silnych, w układzie S-CH-F o określonych parametrach regulujących równowagę (stan równowagi zapewnia optymalny poziom pobudzenia i sprzyja uczeniu się). 
5) Samodzielność w sytuacjach poznawczych podbudowana umiejętnością koncentrowania się na szczegółach, znaczną precyzją w działaniu, potrzebą porządkowania zjawisk, skłonnością do narzucania na rzeczywistość szkieletu logicznego.

6) Odwaga w stosowaniu strategii komunikacyjnych; preferencje dla niekooperacyjnych strategii osiągnięć opartych na języku docelowym.

7) Motywacja instrumentalno-integrująca (wewnętrzna), odzwierciedlająca satysfakcję i przyjemność, jaką daje uczenie się języka; przywiązywanie wagi do walorów poznawczych studiowania i korzyści płynących ze znajomości języka w przyszłości.

8) Umiejętność skutecznego radzenia sobie $w$ trudnych sytuacjach poprzez:

- zachowanie tzw. zimnej krwi,

- wyzwalanie pozytywnych stanów emocjonalnych,

- podejmowanie natychmiastowych wysiłków zmierzających do szybkiego rozwiązania problemu i zmiany sytuacji niesprzyjającej na korzystną (styl radzenia sobie ze stresem skoncentrowany na zadaniu).

Studenci "skazani na sukces” odznaczają się dominacją intelektu (kreatywność połączona z inteligencją) i sumienności (obowiązkowość połączona z motywacją osiągnięć i życiową rozwagą). Są bystrzy, inteligentni, myślący, rozumni, dokładni, obowiązkowi i sumienni. 
